\title{
Promoting public value by implementing reverse logistics in the South African Police Service
}

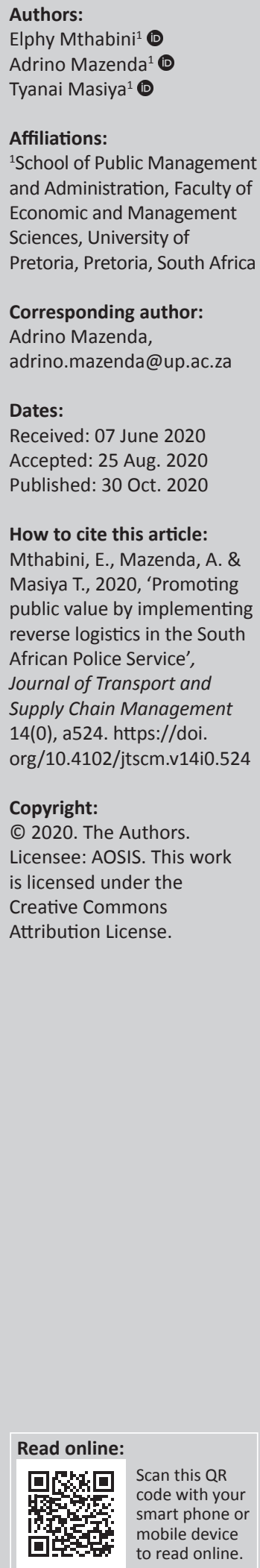

Background: Effective supply chain management (SCM) processes across all South Africa's three spheres of government has become critical in view of increasing demand for public services amidst scarcity of resources.

Objectives: This article provides an assessment of the implementation of reverse logistics within the supply chain management (SCM) system of the South African Police Service (SAPS), in order to produce public value.

Method: The article utilised a qualitative desktop approach, drawing from an extensive review of literature, in particular, SAPS reports, policy documents relevant to journal and online articles on SCM, and reverse logistics.

Results: It is hoped that through the implementation of reverse logistics in SAPS SCM processes, public value is enhanced; there is better financial performance, legislative compliance, employment and preservation of resources. It was found that a shortage of resources, lack of skills, institutional capacity, inadequate control systems and corruption are all detrimental to public value. In order to optimise the efficiency of reverse logistics in enhancing public value, SCM managers must develop policies to manage procurement and resource management processes, as well as implement information systems and automation for the entire reverse flow.

Conclusion: In order to mitigate the reverse logistics challenges and enhance public value in SAPS, there is a need for redesigning the institutional budget priorities, implementation of adequate control measures, recycling of resources, reskilling of SCM personnel, automation and review of the SCM processes.

Keywords: environmental concerns; reverse logistics; public value; supply chain management; South African Police Service.

\section{Introduction}

The need to have effective supply chain management (SCM) processes across all South Africa's three spheres of government has become non-negotiable, as the scarcity of resources and a growing increase in demand for products and services make it almost impossible for any government, or even a household, to function optimally (Shange 2017). The South African Police Service (SAPS) SCM unit is governed by Standing Order, stores 1, Consolidation Notice 5 of 2012, which advocates for the 'whole-of-life cycle approach', which is a method to evaluate every phase in the life cycle of an asset. The life cycle runs through the phases of planning to purchase, acquisition, maintenance and finally disposal (SAPS Annual Report 2014:11). However, this 'Order' does not factor in the element of reverse logistics. In specific, it does not provide for what happens after the disposal of assets. This article makes critical suggestions with regard to the disposal phase. Introducing a product cycle that does not just end at consumption is important; how, after use, a product can be recaptured and reused for the benefit of the public's 'reverse logistics' is, therefore, important to the SAPS. Through the implementation of effective reverse logistics in SAPS SCM processes, public value will be enhanced; there will be better financial performance, legislative compliance, employment and preservation of resources (National Treasury's Public Sector SCM Review 2015:14).

This article, therefore, intends to answer the following questions:

- What does reverse logistics entail in the context of SAPS?

- How does reverse logistics enhance public value in the SAPS?

- What are the challenges facing SAPS in the implementation of reverse logistics?

- What are the recommendations for the effective implementation of reverse logistics in enhancing Public value at SAPS? 
The article draws on a qualitative desktop approach based on extensive review of literature to suggest ways in which the public resources in SAPS could be channelled for efficient usage, through the reverse logistics system, underpinned by Moore and Khagram's (2004:2) public value theory.

The first section of this article provides the research methodology utilised in the study. The second section discusses the conceptual framework to analyse the SCM systems, reverse logistics and public value in public entities. The third section provides results on the challenges faced by SAPS in the implementation of reverse logistics, which are detrimental to the realisation of public value. The fourth section provides recommendations on how SAPS can improve their SCM system towards the implementation of reverse logistics and enhancing public value. The last section provides conclusions to the study.

\section{Research methodology}

This study utilised a qualitative desktop research approach, based on an extensive review of literature. Firstly, the study utilised policy documents to analyse SAPS SCM legislation and policies on reverse logistics and public value. Secondly, progress reports and articles were used to explore reverse logistics execution in SAPS. Finally, assessment reports, journal and online articles were used to explore the challenges facing the SAPS in the implementation of reverse logistics in order to realise public value.

Desktop research involves collection of data from existing sources. The technique is necessary for exploring phenomenon on matters not explored through field research, in particular addressing a gap where the research participants do not have adequate answers to the research questions (Doolan \& Froelicher 2009). Content analysis is utilised to skim through the documents, unearthing themes necessary in addressing the research questions (Kumar 2014).

Key policy documents utilised include the South African Auditor General reports, the Public Finance Management Act (PFMA), 1999 (Act No. 1 of 1999) reports and the SAPS Annual reports. Key progress reports and articles include the SAPS annual reports and literature sources from Cannella, Bruccoleri and Framinan (2016); Moore (1995); Moore and Khagram (2004); Mostert, Niemen and Kotzé (2017) and Vlachos (2016:1). Finally, key assessment reports and articles include Shange (2017), National Treasury SCM Review, SAPS SCM reports and the Department of Monitoring and Evaluation Reports.

\section{The essence of reverse logistics at South African Police Service}

Elmas and Edorgmus (2011:162) define reverse logistics as the process of moving products that cannot be reused for their initial purpose, as a result of damages or deterioration in value to capture value or disposal. Re-manufacturing and refurbishing activities are included in this definition. It is a process by which a company governs the return of its products, parts and materials from consumption sites, in order to reuse them, recover their residual value or dispose of them (Gandolfo \& Sbrana 2008:31-32.)

Reverse logistics means that resources can be reversed into the SCM process through various ways; firstly, reuse; secondly, reconditioning and refurbishments, and finally, remanufacturing (Elmas \& Erdogmus 2011:166-167). The reuse component involves using the product again for the original purpose (conventional use) or fulfilling a different function (creative reuse). For instance, the packaging is reused, or a product is sent back for resale to another customer. The resource can also be repaired/repackaged when a moderate amount of repair and repacking will allow the product to be reused. Recycling forms part of the process when the product is broken down and 'mined' for components that can be reused or resold. Reconditioning is the process of restoring a product's condition by means of repairs so that it can be used again. Refurbishing refers to the distribution process of products that are returned to a supplier for various reasons, such as defects in the product. Refurbishing is similar to reconditioning. It requires the product to be tested first to verify if it functions properly before it can be sold. Remanufacturing is similar to reconditioning and refurbishing. The difference is that it requires more work and repairs to complete disassembly of the product Vlachos (2016:1).

Shange (2017) identifies numerous SCM challenges related to the SAPS that have a negative bearing on service delivery. These challenges include lack of basic resources such as office equipment and other important items, such as cartridges, vehicles and bulletproof. Service delivery has also been affected as officers' demand gargantuan amounts to be spent on the replacement of depleted resources. One of the most effective and efficient solution to these challenges would be to recycle and reuse some, if not all, reusable products, a term known as reverse logistics (Shange 2017).

The implementation of reverse logistics at the SAPS is the ultimate step that will lead to the realisation of public value. Public value is the ultimate goal to be expected upon the successful implementation of reverse logistics. Public value refers to the benefit derived by the citizens from the provision of government services. It is focused on that nonmonetary benefit to the 'consumer' from a given service or governmental action (Baran 1991:806). Public value compels public officials to consider the benefits and costs of public service not only in financial terms but also how government actions affect factors such as equity, autonomy, sensitivity, clarity and public participation (Kavanagh (2014:1). To ensure public value from the SAPS SCM systems, there is a need for effective implementation as well as monitoring and evaluation of reverse logistics.

Studies on reverse logistics agree on implementing the practices to solve cost-related problems (Badenhorst 2013:1-10; Cannella et al. 2016:36; Rutner, Aviles \& Cox 2012:95). In addition, Badenhorst (2016:1-12) argues that the process is 
necessary to mitigate operational barriers. Ramírez (2012:1137) and Vlachos (2016:1) argue that despite the negative picture painted on reverse logistics, on conflicting roles of SCM personnel, the process can lead to improved financial management through recovering the value of products. Thus, based on these assertions, reverse logistics is fundamental in the transformation of public institutions (Peretti et al. 2015:266).

Currently, there are no reverse logistics in place within the SAPS. Implementing reverse logistics will entail old furniture, which includes (old) chairs, tables, desk and fridge; office equipment such as steel cabinet, filing cabinet, pigeon-hole rack, workstation desk, bookcase; home electrical appliances such as fridges, heaters, microwaves, hover; information technology equipment such as computers (CPU), computer screen, scanner, fax machine, overhead projectors, laptops, cell phones, cameras, printers, navigator or global positioning system (GPS), digital decoder, and vehicles that are auctioned and obsolete vehicles that can be crashed and sold to scrap metal dealers for value for money (Cruywagen 2019). Further, empty firearm cartridges can also be sold to scrap metal dealerships; waste paper can be recycled avoiding harmful environmental business practices and promoting sustainable recycling systems and development; old cartridges or used toners or drums can be returned to initial service providers or any service providers/dealers.

In addition, old motor vehicle tyres can also be sold to dealers or returned to the manufacturers, and old car batteries can also be returned through reverse logistics processes (Shange 2017). In addition, boarded miscellaneous equipment and tools such as old or unserviceable air compressors, air conditioners, racks, laminators, step ladders, handcuffs, floor polishers, shredders, heavy-duty staplers, heavy-duty punchers, hacksaws, chisels, pliers, spanners, cutters, hammers, waste bins, retention cords, fluorescent lights or light bars, crime scene handling and first aid boxes can also be considered (Coetzee \& Stott 2008; SAPS 2020).

Implementation of revere logistics at SAPS can be presented through the reverse logistics framework, presented in Figure 1.

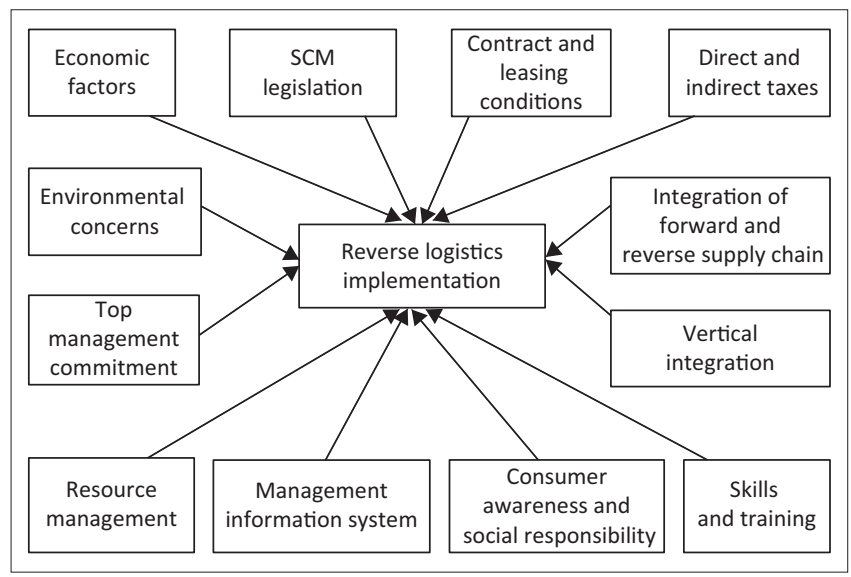

SCM, supply chain management.

FIGURE 1: South African Police Service reverse logistics framework.
Several factors are responsible for reverse logistics implementation. All the factors work through the integration of forward and reverse supply chain. This implies simultaneous management of material, information and monetary flows as suggested by Fleischmann (2001) and Tibben-Lembke and Rogers (2002). According to Mehrbod, Tu and Miao (2014), greater resource utilisation can be achieved through integration of forward and reverse supply chain.

The concept of reverse logistics can be implemented by SAPS to realise public value. Public value is argued to be the goal expected upon the successful implementation of reverse logistics (Moore 1995:43). The public value concept entails that apart from meeting the basic service delivery objective, the public service must ensure quality in their output, which is valued by citizens. The creation of public value reconfigures public management and service delivery (Constable et al. 2008:9). It combines inputs, outputs and outcomes with the aim of achieving collectively desired social outcomes (Moore 1995:43). The reporting on public value is a form of government accountability and compels public officials to consider the implications of their financial related motives/actions, as well as critical societal factors such as equity, autonomy, sensitivity, clarity and public participation (Kavanagh 2014:1).

The public value concept draws from the private sector experiences of private managers' initiatives to achieve private value or economic value (Moore 2004:2). Further, Moore (2004) developed the strategic triangle model to shift the public value concept into the public sector. Thus instead of being economic, as in the case of the private sector, it would be social. The model is presented in Figure 2 and shows the triple factors, namely legitimacy and support, secondly, operational capabilities and lastly, public value.

The legitimacy and support factor acknowledges that there must be a form of authorisation from a range of stakeholders, those who are willing to render their support in any manner needed for the success of value creation. A public official cannot exercise individualism in the public space without authorisation from relevant superiors. In addition, bureaucrats approve government policies and programmes to be implemented as well as the provision of necessary resources and mechanisms to ensure success (Moore \& Khagram

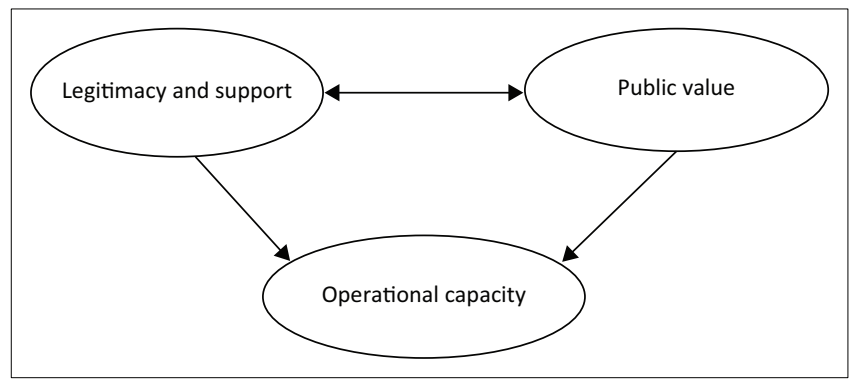

Source: Moore, M. \& Khagram, S., 2004, 'On creating public value: What business might learn from government about strategic management', Working paper of the corporate social responsibility initiative, Kennedy School of Government, Harvard University, Cambridge, MA. FIGURE 2: Strategic triangle. 
2004:11). For public value to be achieved, the citizens must be able to volunteer in government programmes. Resources must be disbursed for the successful implementation of these programmes. Moreover, personnel support services need to be availed for the realisation of public value.

Operational capabilities relate to the capacity and resource availability to deliver services, with the view to ensuring public value. The notion of this factor being, with legitimacy and support, adequate capacity will follow and will, therefore, place the public manager in a position to utilise all available resources effectively and efficiently in a coordinated and sustainable manner. Successful implementation of programmes should account for threats and these should be known to the implementing agencies to mitigate risk (Moore \& Khagram 2004:9). Building operational capacity means that public managers are keen and able to engage in the process of gathering all the needed resources from skills, finances and humans in the achievement of public value (Benington \& Moore 2011:4).

The third component is public value. The component entails that once the manager or an institution has the public's approval, the authority to execute a programme or render a service, as well as the needed financial, material and other forms of support, the public will now derive value from what is being offered. However, the question then becomes, how do you measure this value? Value in service cannot be by the public manager's discretion. An outcome might appear of value to the public manager but the public might not perceive it as such. There must be several people to oversee and derive value in a given governmental programme. The oversight is based on consultation, which is a transparent and democratic process in which public participation is centralised. The public gets to play the monitoring and evaluation role of the programme's performance, looking to inform on the value initially planned by the relevant official.

There must be constant communication and the involvement of all stakeholders (Moore \& Khagram 2004:9). What becomes clear, overall, is the interdependence of the three aspects on one another. Without legitimacy and support, it would be difficult to have the resources needed to create public value. Therefore, public value is derived from reverse logistics in two main ways: environmental and economical. The environmental component entails that society is aware of the need to be caring towards the environment for present and future generations and therefore would benefit particularly by the better management of carbon emissions and waste generation by companies. This protects the population from health-related problems (Rubio \& Jiménez-Parra 2014:1).

The economic costs entail that there is quicker response time than is normally the case when resources have to be booked and arranged with an external supplier. A reduction in response time ensures that there is quicker service delivery, and money is not paid out to an external party for items that are already in the hands of the organisation or institution (Adrade et al. 2014:6). In agreement, Rubio and JiménezParra (2014:1) highlight the benefits of reverse logistics and public value as direct (decreasing the use of raw materials, reduction of disposal costs, creation of added value for end-of-use products) and indirect (demonstration of environmentally responsible behaviour and improved customer relations). To ensure that the process of reverse logistics is performing as planned and achieving expected results, there needs to be a process of monitoring and evaluation. Monitoring means the system is patiently and carefully studied in search of anticipated results (Department of Planning, Monitoring and Evaluation 2017:4). The section 'Challenges to promoting implementing reverse logistics in South African Police Service supply chain management' discusses the challenges to promoting public value through implementing reverse logistics in SAPS SCM.

\section{Challenges to promoting implementing reverse logistics in South African Police Service supply chain management}

Reverse logistics, if successfully implemented, leads to public value (National Treasury's Public Sector SCM Review 2015:14). This section discusses the implementation challenges of reverse logistics in enhancing public value in the SAPS.

\section{Irregular expenditure}

Irregular expenditure in South Africa is a cancer that has retarded the realisation not only of policy implementation but the entire scope of the country's developmental goals. It is easy to identify and adopt policies in the public sector, as evidenced by the myriad laws passed in the National Assembly yearly. If factors such as irregular expenditure were not prevalent, South Africa would arguably be a developed country. Irregular expenditure is a constant threat that can be alleviated, but whether it can be eradicated is a different question. Irregular expenditure arises when there is non-compliance with the SCM processes (Auditor-General [AG] 2017:94). Compliance to outlined rules and processes is a challenge that can be avoided, that can see to it that policies are implemented successfully for the benefit of the public. The 2019 AG) presentation to the Parliamentary Committee revealed a more than $500 \%$ increase in irregular expenditure at SAPS, from R33 million (\$16 322.22) in the 2017/2018 financial year to R996m (\$54 189 770) in the 2018/19 financial year. The money was used without any applicable legislation or in accordance with any SAPS requirements (Louwe 2019). The irregular expenditure activities also relate to the SCM and procurement processes. The failure of SAPS to curb irregular expenditure, according to the Auditor-General (2019), General report (2017/2018), has been due to lack of accountability of personnel and subsequent red tape in solving pending cases. Moreover, instability and understaffing in key positions pose significant operational 
challenges. Finally, the lack of adequate record-keeping standards to support financial and performance reporting has also been blamed (Louwe 2019).

The available funds are not used in accordance with the prescribed guidelines as set out in the National Treasury Guidelines (SAPS Annual Report 2017/2018:22). Financial control measures are not adequate to curb general expenditure, consequently, there are challenges in the institutional design of budget priorities. Deviation from the simple SCM entails that the National Treasury Guideline on procurement processes in mitigating irregular expenditure is not followed. The National Treasury Guideline provides a clear procedure to be followed for the identification and application of irregular expenditure (SAPS 2019:22, Annual Report 2017/2018).

\section{Unskilled staff}

According to the National Treasury's Public Sector SCM Review (2015:5-6), the SCM practitioners do not have the skills, knowledge and experience that they need. The implementation of reverse logistic in enhancing public value requires competency and skills. There is a significant gap in skills and knowledge within the SAPS SCM.

In highlighting the above, Mathevani (2012:5) points out that the SAPS executives struggle to reconfigure the system due to the lack of well-developed previously disadvantaged applicants to occupy advertised posts in certain specialised units, as required by the employment equity plan. The SAPS has had court battles in this regard, as it has failed to advance the transformation agenda effectively (SAPS 2019). In further highlighting the skills shortage in the SAPS, Ross (2008) mentions how his interview with a Democratic Alliance (the official opposition political party in South Africa) member, Diane Kohler-Barnard, pointed to the many staff shortages in the SAPS with some posts remaining vacant for long periods. Additionally, there is a lack of training for station managers and detectives, pointing to the fact that even senior officials in the hierarchy are not sufficiently trained to execute the various mandates of the SAPS. Skills shortage results in outsourcing, which is most costly to the organisation. This has consequences of dysfunctional organisation systems, owing to sabotage of internal policies and systems by dissatisfied employees (Hyman \& Makinana 2018).

According to Hyman and Makinana (2018), the skills challenge is informed by various factors, with three prominent factors being the legacy of apartheid, the intake of already inadequately skilled staff (National Secondary School (NSC) qualified), as well as staff turnover. Adding to these findings, Police Minister Bheki Cele (in Hyman \& Makinana 2018) mentioned that SAPS members were 10000 police fewer than in 2017, losing the United Nations norm of policing, which states one police officer to every 220 citizens (Hyman \& Makinana 2018). This contention is supported by Mnisi (2015:22), who points out that the nature of employment has changed and usually employees stay in organisations for shorter periods. This has created unique challenges because trained employees might leave organisations with vast knowledge and expertise. The organisation will then need to offer learning opportunities that will help the temporal workforce to learn the new work in order to contribute quickly. The skills challenge affects the general SCM processes, as the existing staff have inadequate skills to implement the reverse logistics systems in realising public value. Resources have to be channelled towards the training of the general SCM systems at the expense of the reverse logistics processes.

\section{Institutional design}

With the SCM challenges facing SAPS, questions have to be asked on whether the current design is accommodative of changes. The SAPS is a public institution with structures and a design that has been in place from as far back as pre-South African democracy. The institutional design goes beyond the structural capacity to implement policies that seek to challenge the status quo both internally and with regard to public policy. According to Schute and Meyer (2004), although developing specific knowledge is necessary to accomplish objectives, the actual understanding of this knowledge and its application significantly depends on the preparedness of those so charged with initiating the change. The authors argue that the SAPS tends to be a hyperbureaucracy, characterised by a rigid hierarchical structure, operating as a closed social system where change is not the order of the day. Institutional design also speaks to inherent attitudes and behaviours, thinking processes and ways of execution and all these have a direct impact on the implementation of a policy (Ambe \& Maleka 2016:60). The National Treasury's Public Sector SCM Review (2015:5-6) states that the organisational structures and systems within which the SAPS SCM operate are imperfect due to either inexperienced or under-skilled managers, lack of motivation and inappropriate technological advancement (e.g. internet connections are not available for up-to-date information about the price and availability of goods and services).

According to Badenhorst and Nel (2012:80), reverse flows involve different channels that require new systems of approaches. Organisational SCM systems need to be flexible, not rigid, to implement reverse logistics successfully. Reverse logistics requires drastic changes in both mindset and practice. If some of the key challenges that have hitherto led to policy and SCM failure in the SAPS are not addressed, there is no certainty that they will not continue to affect the overall institutional design.

\section{Political support}

Further, within public institutions also exists the need for political support. Benington and Moore (2011:6) state that public managers need a strong mandate from elected politicians and from their line managers to carry out their tasks. This mandate can be derived legislatively and through the SAPS policies. Nantulya (2018) argues that key state institutions such as SAPS have been systematically and extensively eroded by 
politicians who deliberately weakened and co-opted these institutions, rendering them ineffective and allowing the diversion of public resources to continue unhindered. There is need for political support given the importance of reverse logistics, which brings the capacity and resource availability to deliver services with the view to ensuring public value. With legitimacy and support, adequate capacity will follow and will, therefore, place the public manager in a position to utilise all available resources effectively and efficiently, in a coordinated and sustainable manner.

\section{Corruption}

The SCM of South African government institution, such as SAPS, is characterised by corruption that has affected the realisation of policy implementation. Allegations of corruption in the police's procurement processes have been reported by watchdog institutions including the Standing Committee on Public Accounts (SCOPA), which have argued that many contracts have been awarded through kickbacks and other improprieties (Legalbrief 2019). For example, an investigation showed that the police awarded contracts to Forensic Data Analysts (FDA) for services, including the maintenance of SAPS torches, by paying kickbacks to former Acting Commissioner Khomotso Phahlane (Essop 2017). In 2017, the Independent Police Investigative Directorate (IPID) conducted complex investigations into large-scale corruption in the police's SCM unit (Essop 2017). Interestingly, it is easy to identify and adopt policies in the public sector, as evidenced by the myriad of laws passed in the National Assembly yearly. If corruption was not central in the SCM division of the SAPS, the SCM within SAPS would arguably be one of the best divisions within the SAPS and in particular South African public institutions in terms of public procurement best interest.

The discussion on corruption has mainly centred on the lack of skills to implement reverse logistics within the SAPS but the other important factor is the financial resources necessary to start putting the ideas and thoughts about reverse logistics into a tangible project that brings about the legislative, environmental and monetary advantages. South African Police Service should accommodate the new ideas of public value and the implementation of reverse logistics that will prove a tricky task. Organisational arrangements must be flexible and adaptable so that they can be used as constructive administrative aids to promote effective and efficient public administration.

\section{Inadequate control systems}

The need for adequate control measures stems from the realisation that corruption is at its peak in the public sector and this could only be the result of loopholes in the system of the supply chain that are being exploited by greedy servants. It is the view of the researcher that if control measures are not tightened or used optimally, the implementation of reverse logistics will be subjected to the same fate as all other failed government policies and programmes.
The difficulty of implementing reverse logistics is a result of the absence of indicators that measure the cost-benefit of implementing and operating it. The lack of these indices is related to the non-existence of the knowledge of the costs of the operation (Ambe \& Maleka 2016:60; Shange 2017). Moreover, there is a lack of communication between different control mechanisms or insufficient supervision over contractors which might lead to mismanagement of performance, where there are fewer requirements for transparency (Mostert et al. 2017). It also leaves room for corruption, since the controls are not properly monitored. A Global Corruption Barometer (GCB) Africa survey (Pring \& Vrushi 2019) revealed that SAPS was considered the most corrupt institution in the country (Manyathela 2019). In addition, most monitoring and evaluation systems in SAPS do not integrate valuable information into the policy cycle, to enhance good governance and accountability. The valuable information in these instances includes internal procedures to check whether initial objectives of specific actions are met and are effective (European Commission 2015:73).

Consequently, incidences of continued irregular expenditure in SAPS are reported by Louwe (2019), who details a failure to implement adequate monitoring and controlling mechanisms in the organisation. This relates to the SCM processes, which has a bearing on the implementation of reverse logistics to achieve public value. South African Police Service will more likely find it difficult to implement reverse logistics due to the absence of indicators measuring the costbenefit analysis of implementing the processes. The lack of these indices is related to the non-existent knowledge of the costs of operation (Andrade et al. 2013:5). A report on the Economic and Implementation Evaluation of the Incremental Investment in Forensic Services stated that 'The SAPS must improve its financial management processes and SCM practices to achieve better value for money' (DPME 2017:vi). There is a strong need for the input control of products, correct identification of the status of returned materials and process mapping, in order to instil the reverse logistics mechanisms. The SAPS has few information systems and logistics networks capable of controlling the reverse flow of materials; as such implementation of reverse logistics is a challenge (Andrade et al. 2013:5).

\section{Recommendations}

Successful implementation of reverse logistics in enhancing public value at SAPS requires strong institutional framework underpinned by the following key recommendations, drawing mostly from the activities of SCM practitioners. The recommendations are summarily provided in Table 1 , drawing from the key challenges.

\section{Mitigation of irregular expenditure}

The country's government already has a strained budget that requires careful expenditure. The introduction of reverse logistics will help in cutting expenditures if only it is done in the context of financial discipline in so far as limiting 
TABLE 1: Key challenges and recommendations.

\begin{tabular}{ll}
\hline Key challenges & Recommendations \\
\hline Irregular expenditure & Mitigation of irregular expenditure \\
Corruption & Transparency and access to information \\
Corruption & Eradication of corruption \\
Unskilled staff & Skills training \\
Inadequate control systems & Institutional design \\
Institutional design & Automation \\
Institutional design & Direct reuse \\
\hline
\end{tabular}

irregular expenditures is concerned. Irregular expenditure drains money from the government, which results in some of the programmes and projects not being successfully implemented. Financial control measures must be in place to curb this problem within the SCM division. The National Treasury Guideline must be followed to mitigate irregular expenditure and to apply appropriate procedures in procurement processes and SCM.

\section{Transparency and access to information}

Implementation of reverse logistics in SAPS should involve all employees since they are responsible for the day-to-day running of operations in their respective units. All officers working in SAPS must be aware of the SCM principles and techniques required for the effective functioning of public institutions. Moreover, they should have access to information on SCM and procurement processes in their organisation.

\section{Eradication of corruption}

The successful implementation of reverse logistics maybe affected by corruption which seems to be so rampant in the public sector. The alleviation of corruption requires that regular external audits be conducted. A centralised process of appointing auditors must be established to avoid manipulation of the accounting processes. Stiffer penalties must be imposed on corrupt individuals. This should be coupled with conducting lifestyle audits.

\section{Skills training}

Critical skills are key to the success of an institution. The recruitment system of SAPS and subsequent promotion of officers within the force into different units pose a challenge on the required SCM skills necessary to implement reverse logistical processes in enhancing public value. Internal SCM training mechanisms should not target only personnel in the SCM unit, but all personnel, in different units, on the importance of recycling and re-use of resources, which are critical components of the reverse logistics system. The training should involve private-sector agencies, who have experience in enhancing public value in their organisations. The training should instil a succession plan to cover instances of staff turnover. Moreover, incentives should be established to reward employees on the successful implementation of reverse logistics. The incentives must be based on cost-saving mechanisms.

\section{Institutional design}

Currently, the way the SAPS SCM is structured in terms of the culture, behaviour and reporting systems does not effectively promote the implementation of reverse logistics. The institutional design concept speaks to the institution's ability to handle change, to move with the times without totally breaking down the systems and measures in place to achieve the mission and vision of the institution. For reverse logistics to succeed, there is a need to introduce the concept as a policy tool, centralised with coordinated procedures such as reporting structures. The current design is rigid and non-transformative. It is riddled with bureaucratic bottlenecks which impede the implementation of reverse logistics.

\section{Adequate control measures}

The introduction of reverse logistics will not be a process that simply adds costs to the budget of the institution. Once the reverse logistics system is in place, it will mean that all the resources that the institution has been procuring from the manufacturer will be reproduced internally. This, in essence, results in a restructuring of the budget. Therefore, the budgeting process needs explicit details on what funds are to be spent on and the probable estimate for reserves. The bidding process for all the necessary materials and resources should be transparent and only adopt the cheapest possible cost without compromising the quality.

\section{Automation}

Supply chain management processes in SAPS are administered through the manual system. Key to this practice is the lack of skills to handle the automated SCM systems. This derails the reverse logistics systems from being operational. There is a need to introduce automation. The use of technology is essential as a control mechanism, from procurement through the life cycle of products, and possible recycling, re-use and refurbishments processes.

\section{Direct reuse}

Selling products at a discounted rate to a second-hand market or reusing them in other areas are ways that SAPS can recover costs on items that are no longer saleable in stores. This is attested in Holweg, Teller and Kotzab (2016:651), who concurred that damaged items may be reused in other organisational areas or resold to third parties, thus enabling cost recovery.

\section{Conclusion}

This study advocates for the implementation of reverse logistics within the SCM system of SAPS in pursuit of public value. The study posed the following questions:

- What does reverse logistics entail in the context of SAPS?

- How does reverse logistics enhance public value in the SAPS? 
- What are the challenges facing SAPS in the implementation of reverse logistics?

- What are the recommendations for the effective implementation of reverse logistics in enhancing public value at SAPS?

In addressing these questions, the article drew on Moore's (1995) public value theory to suggest ways in which the public resources in SAPS could be channelled for efficient use. Secondary policy documents, reports and articles were used to unearth the challenges affecting the implementation of reverse logistics in SAPS. Recurrent incidences of irregular expenditure and corruption need to be solved in a more pragmatic approach. For instance, officers whose units are found with qualified audits should pay back into the organisation, regardless of whether the purchases were justifiable. This applies to expenditure done outside the prescribed guidelines.

In line with this, there should be a redesign of the institutional budget priorities which implement adequate control measures. This could come through monitoring and evaluation, reuse as well as automation. The benefit of implementing reverse logistics is that public value will be enhanced through social, environmental and economic benefits. Economically, the organisation will save money from recycling, enabling it to invest this money in other service delivery challenges, such as attending to crime. Environmentally, through recycling, the habitat will be saved from the disposal of hazardous material. Socially, by creating and meeting public satisfaction and expectations as well as trust in the execution of policing duties.

Organisational SCM systems need to be flexible, not to be rigid, in order to implement reverse logistics successfully. Reverse logistics requires drastic changes in both mindset and practice.

South African Police Service managers need a strong mandate from elected politicians and from their line managers to carry out their tasks. This mandate can be derived legislatively and through the policies of the organisation.

\section{Limitations of the study}

Reverse logistics is a new concept as far as receiving academic, public and government attention. The fact that the SAPS as a case study lacks information or documentation of reverse logistics proved a challenge as it made the precise location of the implementation failure impossible. The SAPS does not have any available policy implementation, monitoring and evaluation document. This would have gone straight to suggesting a possible solution to the problem.

\section{Areas for further research}

The article focused on assessing the implementation of reverse logistics in the SCM unit of SAPS. The article relied more on the extensive review of official's documents, which might create a gap for further research using other research methodologies. Future studies can adopt quantitative research or mixed methods where surveys and interview can be used to assess the attitudes of SAPS officials in other clusters in South Africa on their views concerning reverse logistics. It will be fundamental as well to examine the barriers in details of reverse logistics within the public administration domain both in academics and in practise. Questions around the significance of reverse logistics in relation to public value can be asked. Also, within SAPS itself, the implementation, processes of reverse logistics can be examined using the aforementioned methods. So there is an opportunity for future researchers to interrogate more on the significance of reverse logistics not only in SAPS but also in other government departments as well.

\section{Acknowledgements Competing interests}

The authors have declared that no competing interests exist.

\section{Authors' contributions}

E.M. conceived and presented the idea as well as development of the theory. A.M. and T.M. supervised the presentation process and performed the analytical techniques. All authors discussed the results and contributed to the final manuscript.

\section{Ethical consideration}

Ethical clearance was not required for the study.

\section{Funding information}

This research received no specific grant from any funding agency in the public, commercial or not-for-profit sectors.

\section{Data availability statement}

Data sharing is not applicable to this article as no new data were created or analysed.

\section{Disclaimer}

The views and opinions expressed in this article are those of the authors and do not necessarily reflect the official policy or position of any affiliated agency of the authors.

\section{References}

Adrade, R.P., Lucato, W.C., Vanalle, R. \& Vieira, Jr. M., 2014, Review of the relationship between reverse logistics and competitiveness, Advanced Materials Research 845(2014), 614-617. https://doi.org/10.4028/www.scientific.net/AMR.845.614

Ambe, I.M. \& Maleka, T., 2016, 'Exploring supply chain management practices within municipalities in the West Rand district', Problems and Perspectives in Management 14(3-3), 657-666. https://doi.org/10.21511/ppm.14(3-3).2016.09

Auditor-General, 2017, Public financial management act report, Government Printers, Pretoria.

Auditor-General, 2019, AGSA MFMA General Report - National. Government Printers, Pretoria.

Badenhorst, A., 2013, 'A framework for prioritising practices to overcome cost-related problems in reverse logistics', Journal of Transport and Supply Chain Management 7(1), a113. https://doi.org/10.4102/jtscm.v7i1.113 
Badenhorst, A., 2016, 'Prioritising the implementation of practices to overcome operational barriers in reverse logistics', Journal of Transport and Supply Chain operational barriers in reverse logistics', Journal of Transport and
Management 10(1), a240. https://doi.org/10.4102/jtscm.v10i1.240

Badenhorst, A. \& Nel, J.D., 2012, Identifying potential solutions, viewed 26 October 2019, from https://jtscm.co.za/index.php/jtscm/article/view/32/30

Benington, J. \& Moore, H.M., 2011, Public value in complex and changing times in public value: Theory and practice, Palgrave Macmillan, Basingstoke.

Baran, P., 1991, Werte [Waardes], in H.J. Sandkühler (ed.), Europäische Enzyklopädie zu Philosophie und Wissenschaften, 4, pp. 805-815. Felix Meiner Verlag, Hamburg.

Cannella, S., Bruccoleri, M. \& Framinan, J.M., 2016, 'Closed-loop supply chains: What re verse logistics factors influence performance?', International Journal of Production Economics 175(1), 35-49. https://doi.org/10.1016/j.ijpe.2016.01.012

Coetzee, B. \& Stott, N., 2008, Destroying firearms contributes to peace in Southern Africa, viewed 20 February 2020, from https://issafrica.org/iss-today/destroyingfirearms-contributes-to-peace-in-southern-africa.

Constable, S., Passmore, E. \& Coats, D., 2008, Public Value and Local Accountability in the NHS. Work Foundation, London.

Cruywagen, V., 2019, 'Ammunition shortage leaves cops at risk', Cape Argus News, 28 August, viewed 23 January 2020, from https://www.iol.co.za/capeargus/news/ ammunition-shortage-leaves-cops-at-risk-31418203.

Department of Planning, Monitoring and Evaluation (DPME), 2017, Annual report viewed 23 February, 2017/2018, from https://www.dpme.gov.za/publications/ Strategic\%20Plan\%20and\%20Annual\%20Reports/DPME\%20ANNUAL\%20 REPORT\%202016\%202017.pdf.

Doolan, D. \& Froelicher, E.S., 2009, 'Using an existing data set to answer new research questions: A methodological review', Research and Theory for Nursing Practice 23(3), 203-215. https://doi.org/10.1891/1541-6577.23.3.203

Elmas, G. \& Erdogmus, F., 2011, 'The importance of reverse logistics', International Journal of Business and Management Studies 3(1), 161-171, viewed 11 April 2019, from https://dergipark.org.tr/en/pub/ijbms/issue/26068/274692.

Essop, R., 2017, 'IPID probing large-scale corruption in SAPS supply chain unit', n.d Eyewitness News, viewed 23 January 2020, from https://ewn.co.za/2017/11/30/ ipid-probing-large-scale-corruption-in-saps-supply-chain-unit.

European Commission, 2015, Technical handbook on the monitoring and evaluation framework of the common agricultural policy 2014-2020, viewed 26 January 2020, from https://ec.europa.eu/info/sites/info/files/food-farming-fisheries/key policies/documents/technical-handbook-monitoring-evaluation-framework_ june17_en.pdf.

Fleischmann, M., 2001, 'Reverse logistics network structures and design', in V.D.R. Guide, J.r \& L.N. Van Wassenhove (eds.), Business aspects of closed-loop supply chains, pp. 117-148, Carnegie Bosch Institute, Pittsburgh, PA.

Gandolfo, A. \& Sbrana, R., 2008, 'Reverse logistics and market-driven management' SYMPHONYA Emerging Issues in Management 1(2), 31-32. https://doi.org/ 10.4468/2008.2.03gandolfo.sbrana

Holweg, C., Teller, C. \& Kotzab, H., 2016, 'Unsaleable grocery products, their residual value and instore logistics', International Journal of Physical Distribution and Logistics Management 46(6), 634-658. https://doi.org/10.1108/IJPDLM-11 2014-0285

Hyman, A. \& Makinana, A., 2018, SA's 62,000 police deficit falls short of UN norm for policing, viewed 20 January 2020, from https://www.timeslive.co.za/news/southafrica/2018-09-11-sas-62000-police-deficit-falls-short-of-un-norm-for-policing/.

Kavanagh, S., 2014, Defining and creating value for the public, viewed 27 October 2019, from https://www.gfoa.org/sites/default/files/GFROct1457_0.pdf.

Kumar, R., 2014, Research methodology: A step-by-step guide for beginners, 4th edn. Sage, London.

Legalbrief, 2019, MPs tackle SAPS over questionable contracts, reviewed 20 January 2020, from https://legalbrief.co.za/diary/legalbrief-forensic/story/mps-tacklesaps-over-questionable-contracts/print/.

Louwe, A., 2019, SAPS irregular expenditure increases by almost 3000\%, viewed 13 September 2019, from https://www.politicsweb.co.za/politics/saps-irregularexpenditure-increases-by-almost-300.

Manyathela, C., 2019, SAPS considered most corrupt institution in SA - Survey, viewed 17 December 2019, from https://ewn.co.za/2019/07/11/saps-considered-mostcorrupt-institution-in-sa-survey.
Mathevani, M.A., 2012, 'An investigation of employee satisfaction in the workplace of the South African Police Service', Unpublished master's thesis, University of Johannesburg, Johannesburg.

Mehrbod, M., Tu, N. \& Miao, L., 2014, 'A hybrid solution approach for a multi-objective closed-loop logistics network under uncertainty', International Journal of Industrial Engineering 11(1), 237-252. https://doi.org/10.1007/s40092-014-0089-z

Mnisi, B.N., 2015, 'An evaluation of training and development for the South African police service: A case of Vereeniging cluster', Unpublished master's thesis, University of the North West, Potchefstroom.

Moore, M., 1995, Creating public value, Harvard University Press, Cambridge, MA.

Moore, M. \& Khagram, S., 2004, 'On creating public value: What business might learn from government about strategic management', Working paper of the corporate social responsibility initiative, Kennedy School of Government, Harvard University, Cambridge, MA

Mostert, W., Niemann, W. \& Kotzé, T., 2017, 'Supply chain integration in the product return process: A study of consumer electronics retailers', Acta Commercii 17(1), 1-18, a487. https://doi.org/10.4102/ac.v17i1.487

National Treasury's Public Sector SCM Review, 2015, Public Sector Supply Chain Management Review, Government Printers, Pretoria.

Nantulya, P., 2018, 'South Africa's Strategic Priorities for Reform and Renewal', African Center for Strategic Studies, 17 February, viewed 13 March 2019, from https:// africacenter.org/spotlight/south-africas-strategic-priorities-reform-renewal/.

Peretti, U., Tatham, P., Wu, Y. \& Sgarbossa, F., 2015, 'Reverse logistics in humanitarian operations: Challenges and opportunities', Journal of Humanitarian Logistics and Supply Chain Management 5(2), 253-274. https://doi.org/10.1108/ JHLSCM-07-2014-0026

Pring, C. \& Vrushi J., 2019, 'Global Corruption Barometer Africa 2019 - Citizens' view and experiences of corruption', Transparency International, Berlin, Germany, viewed 9 March 2019, from https://afrobarometer.org/sites/default/files/ publications/Publications\%20conjointes/partenaires/ab_r7_global_corruption_ barometer_report.pdf.

Ramírez, A.M., 2012, 'Product return and logistics knowledge: Influence on performance of the firm', Transportation Research 48(6), 1137-1151. https://doi org/10.1016/j.tre.2012.06.001

Ross, K., 2008, 'Police hampered by resources, skills shortage', IOL News, viewed 7 November 2008, from https://www.iol.co.za/news/south-africa/policehampered-by-resources-skills-shortage-423425.

Rubio, S. \& Jiménez-Parra, B., 2014, 'Reverse logistics: Overview and challenges for supply chain management', International Journal of Engineering Business Management 6(12), 1-7. https://doi.org/10.5772/58826

Rutner, S.M., Aviles, M. \& Cox, S., 2012, 'Logistics evolution: A comparison of military and commercial logistics thought', The International Journal of Logistics Management 23(1), 96-118. https://doi.org/10.1108/09574091211226948

Schute, N. \& Meyer, E.M., 2004, Strategic Management in the South African Police Service: An Examination of Management Preparedness, viewed 12 February 2019, from https://www.ncjrs.gov/pdffiles1/nij/mesko/207995.pdf.

Shange, N., 2017, Ekurhuleni Cops office bound because of bullet shortages, viewed 17 September 2020, from https://www.timeslive.co.za/news/south-africa/2017-0718-ekurhuleni-cops-office-bound-because-of-bullet-shortages.

South African Police Service (SAPS), 2014, Annual report, Government Printers, Pretoria.

South Africa Police Service (SAPS), 2019, Speaker notes: Lieutenant General BC Mgwenya National Recruitment Indaba, viewed 20 November 2020, from https:// www.saps.gov.za/newsroom/msspeechdetail.php?nid=21432.

South African Police Service (SAPS), 2019, South African Police Service Annual Report, Government Printers, Pretoria.

South Africa Police Service (SAPS), 2020, Disposal of redundant SAPS aircraft helicopters BO-105 and spare parts: Nationally. Tender No 19/1/9/1/80TV (18), viewed 20 January 2020 from https://tenderbulletins co.za/tender-bulletin/disposal-ofredundant-saps-aircraft-helicopters-bo-105-and-spare-parts-nationally-2/.

Tibben-Lembke, R.S. \& Rogers, D.S., 2002, 'Differences between forward and reverse logistics in a retail environment', Supply Chain Management Journal 7(5), 271-282. https://doi.org/10.1108/13598540210447719

Vlachos, I.P., 2016, 'Reverse logistics capabilities and firm performance: The mediating role of business strategy', International Journal of Logistics Research and Applications 1(1), 1-19. https://doi.org/10.1080/13675567.2015.1115471 